Seminar Nasional Teknologi Informasi dan Kedirgantaraan (SENATIK)

Vol. II, 26 November 2016, ISSN: 2528-1666

\title{
RANCANGAN PERBAIKAN MEJA KERJA DENGAN METODE QUICK EXPOSURE CHECK (QEC) DAN ANTROPOMETRI DI PABRIK TAHU SUMEDANG
}

\author{
Benedikta Anna ${ }^{1}$, Rahmat Sofian $^{2}$, Annisa Purbasari $^{3}$ \\ Universitas Riau Kepulauan Batam, \\ Jl. Batu Aji Baru, Batam, Kepulauan Riau \\ Email: 'b.anna79@gmail.com, ${ }^{2}$ rahmatsofian773@yahoo.co.id, ${ }^{3}$ annisapurbasari@gmail.com
}

\begin{abstract}
Soaking and cleaning raw material soybeans is one of manual material handling of tofu proces. In this process, operators lift the water with a hunched position, regardless of their health, comfort, and safety, then finally will impact to lower back pain.

This research aims to design a ergonomic table of raw materials soybean based on anthropometry operators by Quick Exposure Check at UKM Tahu Sumedang. The data collection is done by field studies, interviews with workers, such as questionnaires and anthropometric data for example posture of workers that covers the back, arms / shoulders, wrists, and neck to do data processing using QEC method (quick exposure check).

The result is shown that the average percentage of exposure level for six workers was $72 \%$ that need action to be taken, namely improvement of working table. The design size of working table using ergonomic wastafel principles which anthropometric measurements for arm $=67.01 \mathrm{~cm}$, long-range hand $=167.30 \mathrm{~cm}$, standing elbow height $=122.94 \mathrm{~cm}$. The percentage of QEC after improvement is decrease become $36 \%$, it means design can reduce complaints and taste below the maximum \% QEC (40\%)
\end{abstract}

Kata kunci: work posture, QEC, anthropometry, wastafel table

\section{Pendahuluan}

Menurut Santoso [1] meningkatkan produktivitas kerja merupakan tujuan utama diperlukannya ergonomi. Sistem kerja yang baik harus bisa menjadikan manusia beraktivitas dengan maksimal. Interaksi yang sering dilakukan dalam sistem kerja adalah interaksi antara manusia dengan mesin. Hubungan ini sering disebut sebagai interaksi manusia-mesin (human-machine system). Wujud dari hubungan ini dapat berupa kombinasi satu atau lebih manusia dengan satu atau lebih komponen fisik untuk saling berinteraksi. Sedangkan kegiatan yang dilakukan oleh interaksi manusia-mesin adalah proses input, operasi dan hasil output yang diinginkan. Untuk mendapatkan sebuah sistem kerja yang baik, maka diperlukan proses perancangan sistem kerja. Selain itu dalam produktivitas dapat meningkat dengan memperhatikan sistem kerja, sistem kerja yang lebih baik dari sistem kerja yang telah ada merupakan salah satu tujuan yang ingin dicapai dalam suatu industri [2]

Sebuah perancangan sistem yang ideal adalah keterlibatan karakteristik manusia pada sebuah sistem terutama interaksi manusia-mesin.Potensi yang ada pada diri manusia, meliputi kemampuan dan keterbatasannya, disesuaikan dengan jenis pekerjaan yang dilaksanakan oleh manusia.Konsep ini sering disebut sebagai "fitting the job to the man".

Pabrik UKM tahu sumedang dalam menjalankan produksi memiliki interaksi sistem. Pabrik ini menghasilkan produk utama yaitu tahu kuning atau tahu sumedang dan tahu putih. Total karyawan pada UKM ini yaitu 6 orang, 2 di antaranya di bagian stasiun penggilingan. Proses pembuatan tahu meliputi perendaman kedelai, stasiun penggilingan, stasiun perebusan, stasiun 
penyaringan (air cuka + hasil perebusan), stasiun pencetakan, perebusan tahu kuning, dan stasiun pendinginan.

Salah satu proses manual material handling adalah proses perendaman dan pembersihan bahan baku kacang kedelai. Dalam proses tersebut operator mengangkat air dengan posisi membungkuk, tanpa memperhatikan kesehatan, rasa nyaman, dan keselamatan anggota tubuh operatornya. Selain itu operator mengalami rasa nyeri di bahu, sehingga dari latar belakang ini penulis mengangkat menjadi penelitian untuk dilakukan perbaikan. Salah satu metode Ergonomic untuk menganalisa beban postur adalah dengan metode QEC (Quick Exposure Check) yang berisi check sheet penilaian keluhan akibat kelelahan di area pinggang, lengan, pergelangan tangan, dan leher. Aplikasi penggunaan QEC sudah banyak ditemui di antaranya usulan meja dan kursi untuk operator bekerja duduk berdiri [3] dengan hasil setelah usulan QEC pada range 40-49\% dimana hanya perlu dilakukan penelitian lanjut dan lebih aman digunakan oleh operator dibanding sebelumnya.

\section{Metode Penelitian}

Obyek yang akan di teliti yaitu meja kerja (meja kerja untuk bahan baku kacang kedelai) yang ergonomis dan posisi kerja berdiri untuk operator pabrik UKM tahu sumedang.

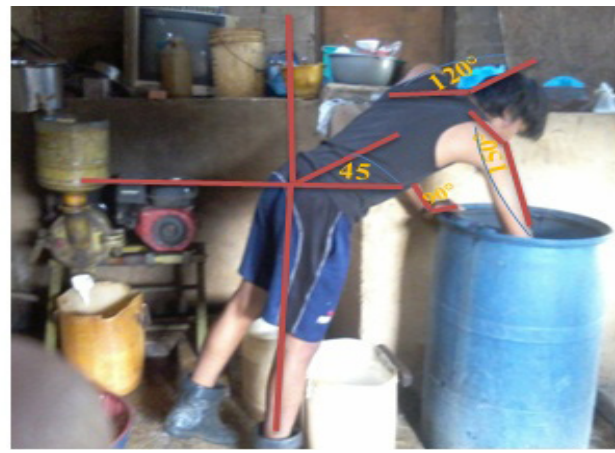

Gambar 1 Proses pengangkatan air untuk direndam ke bahan baku
Gambar diatas adalah proses manual material handling pada stasiun penggilingan oleh operator, dimana bahan baku kacang kedelai berada di bawah dan operator mengangkat air untuk direndam ke bahan baku kacang kedelai.

Untuk membuat rancangan meja kerja bahan baku kacang kedelai beberapa analisa digunakan yaitu:

\subsection{Ergonomi}

Interaksi yang sering dilakukan dalam sistem kerja adalah interaksi antara manusia dengan mesin. Hubungan ini sering disebut sebagai interaksi manusia-mesin (human-machine system). Wujud dari hubungan ini dapat berupa kombinasi satu atau lebih manusia dengan satu atau lebih komponen fisik untuk saling berinteraksi. Sedangkan kegiatan yang dilakukan oleh interaksi manusia-mesin adalah proses input, operasi dan hasil output yang diinginkan.

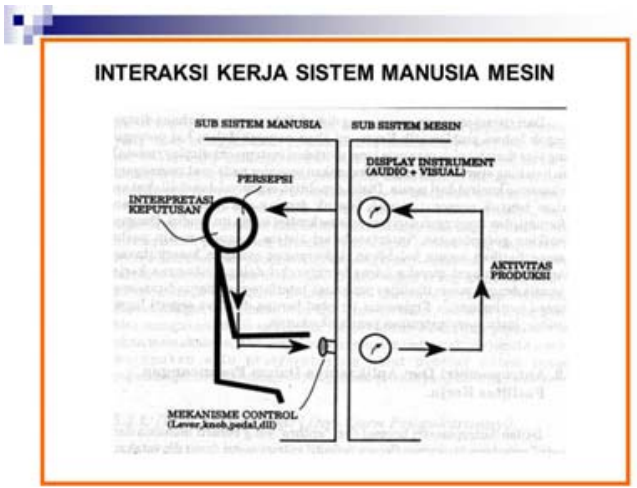

Gambar 2 Interaksi Kerja dalam Sistem Manusia Mesin

\subsection{Quick Exposure Check (QEC)}

Quick Exposure Check (QEC) merupakan suatu metode untuk penilaian terhadap resiko kerja yang berhubungan dengan gangguan otot di tempat kerja.Metode ini menilai gangguan resiko yang terjadi pada bagian belakang punggung, bahu/lengan, pergelangan tangan, dan leher. QEC membantu untuk mencegah terjadinya WMSD's seperti gerak repetitive, gaya tekan, postur yang salah, dan durasi kerja [4] 
Tabel 1 Exposure Score

\begin{tabular}{|l|l|l|l|l|}
\hline \multicolumn{1}{|c|}{ Score } & Rendah & Sedang & Tinggi & $\begin{array}{l}\text { Sangat } \\
\text { Tinggi }\end{array}$ \\
$\begin{array}{l}\text { Punggung } \\
\text { (statis) }\end{array}$ & $8-15$ & $16-22$ & $23-29$ & $29-42$ \\
$\begin{array}{l}\text { Punggung } \\
\text { (bergerak) } \\
\text { Bahu/Lengan }\end{array}$ & $10-20$ & $21-30$ & $31-40$ & $41-56$ \\
\hline $\begin{array}{l}\text { Pergelangan } \\
\text { Tangan }\end{array}$ & $10-20$ & $21-30$ & $31-40$ & $41-56$ \\
\hline Leher & $4-6$ & $8-10$ & $12-14$ & $16-18$ \\
\hline
\end{tabular}

Hasil dari total exposure ini kemudian akan digunakan untuk menghitung nilai exposure level menggunakan rumus :

$\mathrm{E}(\%)=\frac{\mathrm{X}}{\mathrm{Xmax}} 100 \%$

Dimana:

$\mathrm{X}=$ Total skor yang didapat untuk paparan risiko cedera untuk punggung, bahu/lengan, pergelangan tangan, dan leher yang diperoleh dari perhitungan $\mathrm{X} \max =$ Total maksimum skor untuk paparan yang mungkin terjadi untuk punggung, bahu/lengan, pergelangan tangan, dan leher.

Xmax adalah konstan untuk tipe - tipe tugas tertentu. Pemberian skor maximum ( Xmax $=162$ ) apabila tipe tubuh adalah statis, termasuk duduk atau berdiri tanpa pengulangan ( repetitive ) yang sering dan penggunaan tenaga/beban yang relatif lebih rendah. Untuk pemberian skor maximum

$(\mathrm{X} \max =178)$ apabila melakukan material handling yaitu mengangkat, mendorong, menarik dan membawa beban.

Tabel 2 Action level

\begin{tabular}{|c|c|c|}
\hline $\begin{array}{c}\text { Jumlah } \\
\text { skor }\end{array}$ & $\begin{array}{c}\text { Action } \\
\text { level }\end{array}$ & Penanganan \\
\hline $\begin{array}{c}\text { Kurang } \\
\text { dari } 70\end{array}$ & $\begin{array}{c}\text { Action } \\
\text { level } 1\end{array}$ & Nilai tersebut dapat diterima \\
\hline $70-88$ & $\begin{array}{c}\text { Action } \\
\text { level } 2\end{array}$ & Investigasi lebih lanjut \\
\hline $89-123$ & $\begin{array}{c}\text { Action } \\
\text { level } 3\end{array}$ & $\begin{array}{c}\text { Investigasi lebih lanjut dan } \\
\text { dilakukan penanganan dalam } \\
\text { waktu dekat }\end{array}$ \\
\hline $\begin{array}{c}\text { Lebih } \\
\text { dari 123 }\end{array}$ & $\begin{array}{c}\text { Action } \\
\text { level } 4\end{array}$ & $\begin{array}{c}\text { Investigasi lebih lanjut } \\
\text { dan dilakukan penanganan } \\
\text { secepatnya }\end{array}$ \\
\hline
\end{tabular}

\subsection{Antropmetri}

Antropometri menurut Stevenson (1989) dalam Nurmianto [5] adalah satu kumpulan data numerik yang berhubungan dengan karakteristik fisik tubuh manusia ,ukuran, bentuk dan kekuatan serta penerapan dari data tersebut untuk penanganan masalah desain. Antropometri secara luas akan digunakan sebagai pertimbangan - pertimbangan ergonomis dalam memerlukan interaksi manusia. Dalam menentukan posisi tubuh dalam bekerja sangat ditentukan oleh jenis pekerjaan yang dilakukan.

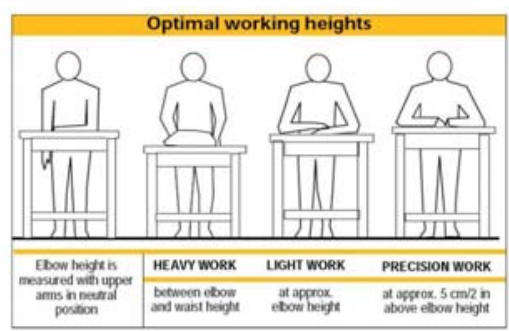

Gambar 3 Posisi kerja seharusnya

Pada gambar 2 menjelaskan untuk meja kerja untuk posisi kerja berdiri yang disesuaikan dengan antropometri manusia yang bekerja. Menurut Iriastadi dan Yassierli [6] bahwa stasiun kerja yang mengharuskan operator berdiri tidak begitu disukai, tetapi sering kali diperlukan. Terutama untuk pekerjaan dengan kondisi sebagai berikut :

- Pekerjaan membutuhkan penanganan barang/ material yang sering, apalagi jika materialnya berat

- Pekerjaan membutuhkan aktivitas menjangkau

- Pekerjaan membutuhkan mobilitas yang cukup tinggi, misalnya berpindah di sekitar srasiun kerja.

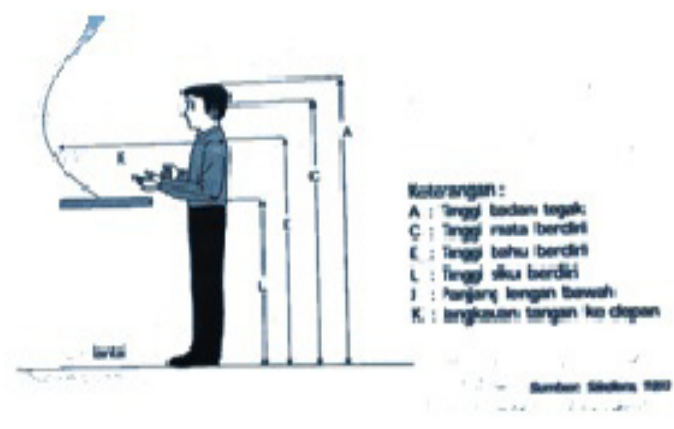

Gambar 4 Posisi kerja berdiri 
Dalam perancangan meja kerja dengan prinsip wastafel untuk stasiun kerja berdiri, dimensi-dimensi kritis pada gambar 4 perlu diperhatikan meliputi : tinggi siku berdiri, jangkauan tangan, rentang tangan. Menurut Pulat dan Clark dalam Tarwaka [4] memberikan pertimbangan tentang pekerjaan yang paling baik dilakukan posisi berdiri yaitu :

1. Tidak tersedia tempat untuk kaki dan lutut

2. Harus memegang obyek yang berat ( lebih dari $4,5 \mathrm{~kg}$ )

3. Sering menjangkau keatas kebawah dan kesamping

4. Sering dilakukan pekerjaan dengan menekan ke bawah

5. Diperlukan mobilitas yang tinggi

Bagian sikap kerja dari pekerja yang diamati meliputi pergerakan tubuh dari bagian punggung, bahu, tangan, dan kaki (termasuk paha, lutut, pergelangan kaki) [7]. Pada dasarnya bekerja sambil berdiri itu sendiri lebih melelahkan dari pada bekerja sambil duduk dan energi yang dikeluarkan untuk bekerja sambil berdiri lebih banyak $10-15$ $\%$ dibandingkan dengan bekerja sambil duduk. Menurut pulat dan Clark dalam Tarwaka [8] memberikan pertimbangan tentang pekerjaan yang paling baik dilakukan posisi berdiri yaitu :

1. Tidak tersedia tempat untuk kaki dan lutut

2. Harus memegang obyek yang berat (lebih dari $4,5 \mathrm{~kg})$

3. Sering menjangkau ke atas ke bawah dan ke samping

4. Sering dilakukan pekerjaan dengan menekan ke bawah

5. Diperlukan mobilitas yang tinggi

Pada dasarnya bekerja sambil berdiri itu sendiri lebih melelahkan dari pada bekerja sambil duduk dan energi yang dikeluarkan untuk bekerja sambil berdiri lebih banyak 10-15\% dibandingkan dengan bekerja sambil duduk.

Dimensi pengukuran antropometri dinamis dilakukan pada saat tubuh sedang melakukan aktifitas fisik. Pengukuran tersebut antara lain meliputi jangkauan, lebar jalan lalu lalang untuk orang yang sedang berjalan, termasuk juga pengukuran kisaran gerak untuk variasi sendi dan persendian, tenaga injak pada kaki, kekuatan jari menggenggam.

\subsection{Pengujian Statistik}

a. Uji Keseragaman Data

Untuk mengetahui data yang digunakan seragam atau tidak maka dilakukan uji keseragaman data [8]. Cara melakukan uji keseragaman data yaitu:

1. Menghitung rata - rata

$$
\begin{aligned}
& \bar{x}=\frac{\sum x_{i}}{n} \\
& \bar{x}=\text { rata }- \text { rata } \\
& \mathrm{xi}=\text { data ke } \mathrm{i} \\
& \mathrm{N}=\text { jumlah data }
\end{aligned}
$$

2. Menghitung standar deviasi

$$
\mathrm{S}=\frac{\sqrt{\sum y^{2}-\left(\sum_{y}\right)^{2} / n}}{n-1}
$$

$\mathrm{SD}=$ Jumlah hasil perkalian antara frekuensi masing - masing skor, dengan deviasi skor yang telah dikuadratkan.

$\mathrm{N}=$ Number of cases

3. Menghitung BKA dan BKB

$$
\begin{aligned}
& \mathrm{BKA}=\bar{x}+(2 \mathrm{x} \mathrm{SD}) \\
& \mathrm{BKB}=\bar{x}-(2 \mathrm{x} \mathrm{SD})
\end{aligned}
$$

b. Persentil

Persentil merupakan suatu nilai yang menyatakan bahwa persentase tertentu dari sekelompok orang yang dimensinya sama dengan atau lebih rendah dari nilai tersebut. Adapun untuk menghitung persentil yang digunakan sebagai dasar perhitungan dapat di lihat pada tabel perhitungan berikut :

\begin{tabular}{|c|c|}
\hline Percentile & Perhitungan \\
\hline 1-st & $X-2.325 \sigma_{x}$ \\
\hline 2.5-th & $X-1.96 \sigma_{x}$ \\
\hline 5-th & $X-1.645 \sigma_{x}$ \\
\hline 10-th & $X-1.28 \sigma_{x}$ \\
\hline 50-th & $X$ \\
\hline 90-th & $X+1.28 \sigma_{x}$ \\
\hline 95-th & $X+1.645 \sigma_{x}$ \\
\hline 97.5-th & $X+1.96 \sigma_{x}$ \\
\hline 99-th & $X+2.325 \sigma_{x}$ \\
\hline
\end{tabular}

Tabel 3 Macam Persentil dan cara perhitungan dalam distribusi normal 
Dari tabel macam persentil dan untuk menghitung besaran nilai dalam distribusi normal diatas dapat digunakan sebagai referensi penghitungan.

\section{Hasil Dan Pembahasan}

\section{Sikap dan Postur Kerja}

Berikut adalah salah satu hasil QEC dari penilaian tabel 4.:

Tabel 4. Salah satu hasil perhitungan QEC untuk operator

\begin{tabular}{|c|c|c|c|}
\hline No & Kriteria & $\mathrm{Ya}$ & Tidak \\
\hline \multicolumn{4}{|c|}{ Postur Punggung (A) } \\
\hline 1 & Hampir Netral & & $\checkmark$ \\
\hline 2 & Agak tertekuk/miring & $\checkmark$ & \\
\hline 3 & Terlalu menekuk/miring & & $\checkmark$ \\
\hline 4 & $\begin{array}{l}\text { Hampir selalu dalam posisi statis ( } \\
\text { B2 ) }\end{array}$ & & $\checkmark$ \\
\hline \multicolumn{4}{|c|}{ Postur Bahu/lengan ( C ) } \\
\hline 1 & Tepat atau dibawah pinggang & & $\checkmark$ \\
\hline 2 & Di sekitar dada & $\checkmark$ & \\
\hline 3 & Tepat atau diatas bahu & & $\checkmark$ \\
\hline 4 & Pergerakan bahu sering ( D2 ) & $\checkmark$ & \\
\hline \multicolumn{4}{|c|}{ Postur Tangan /pergelangan tangan (E) } \\
\hline 1 & Hampir lurus & & $\mathrm{P}$ \\
\hline 2 & Menekuk/ bengkok & $\checkmark$ & \\
\hline 3 & $\begin{array}{l}\text { Pola gerak yang sama dan berulang } \\
\text { 11- } 20 \text { kali per menit ( F2 ) }\end{array}$ & $\checkmark$ & \\
\hline \multicolumn{4}{|c|}{ Postur Tubuh $(\mathrm{G})$} \\
\hline 1 & normal & & $\checkmark$ \\
\hline 2 & Leher hampir tertekuk & & $\checkmark$ \\
\hline 3 & Leher sering tertekuk & $\checkmark$ & \\
\hline
\end{tabular}

Dari tabel di atas menjelaskan bahwa postur punggung pada level A2 yaitu agak membungkuk dengan sudut punggung $45 \square$ seperti pada gambar 1 . kaki tidak berdiri tegak dan tangan membentuk sudut $150^{\circ}$, kepala juga menunduk yang mengakibatkan kelelahan pada bagian leher, bahu, pinggang, punggung serta tangan. Hal ini jika dilakukan berulang kali dapat mengakibatkan penyakit akibat kerja yang berasal dari sikap postur kerja yang tidak ergonomis karena tidak adanya fasilitas kerja yang tidak sesuai dengan antropometri pekerja. Pada kondisi ini skor postur punggung adalah 36 untuk operator 1. Operator seharusnya bekerja dalam posisi berdiri tegak, dengan lengan atas dalam posisi santai dan dalam posisi vertikal dengan yang dekat dengan meja, dan dengan bawah inklinasi (dimiringkan sedikit) dari kedudukan horizontal. Hal ini dapat dicapai jika ketinggian tempat kerja kira- kira $5 \mathrm{~cm}$ dibawah tinggi siku operator [9].

Pada skor Postur bahu/lengan berada pada level $\mathrm{C} 2$ yaitu berada di sekitar dada dan pergerakan bahu sering (D2) dengan skor antara C2 dan $\mathrm{H} 2$ (beban cukup berat) yaitu 6. Hubungan antara $\mathrm{C} 2$ dan I3 (durasi lebih dari 4 jam) dengan skor 8 . Hubungan antara $\mathrm{I} 3$ dan $\mathrm{H} 2$ dengan skor 8, hubungan antara $\mathrm{D} 2$ dan $\mathrm{H} 2$ dengan skor 6 , hubungan antara D2 dan I3 dengan skor 8. Bila dijumlahkan total skor untuk bahu/lengan adalah 36. Pada postur tangan/ pergelangan tangan berada pada level E2 (menekuk/ bengkok), dan pola gerak yang sama dan berulang 11 -20 kali per menit berada pada level F2. Hubungan antara F2 dan J2 memiliki skor 6, hubungan antara F2 dan I3 memiliki skor 8, hubungan antara I3 dan J2 memiliki skor 8, Hubungan antara E2 dan J2 memiliki skor 6, Hubungan antara E2 dan I3 memiliki skor 8 . Jadi jumlah skor untuk pergelangan tangan/bahu adalah 36. Untuk Postur leher pada tabel yaitu leher berada pada level G3 yaitu leher sering tertekuk. Maka hubungan antara G3 dan I3 memiliki skor 10, dan K1 dan I3 memiliki skor 6. Jumlah skor untuk posisi leher adalah 16.

Dari hasil penilaian dan perhitungan skor pada pekerja 1 di atas, dapat mewakili perhitungan pekerja lainnya. Maka didapatkan rekapitulasinya sebagai berikut. Dari proses perendaman, pembersihan kedelai, inspeksi, penggilingan kedelai, dan penyimpanan dari ke enam pekerja tersebut.

Tabel 5 Hasil Skor QEC

\begin{tabular}{|c|c|c|c|c|c|c|c|}
\hline \multirow[b]{2}{*}{ Skor } & \multicolumn{6}{|c|}{ Pekerja } & \multirow{2}{*}{$\begin{array}{c}\text { Rata } \\
- \\
\text { rata }\end{array}$} \\
\hline & 1 & 2 & 3 & 4 & 5 & 6 & \\
\hline Punggung & 36 & 22 & 22 & 22 & 22 & 22 & 24.3 \\
\hline Bahu/lengan & 36 & 34 & 30 & 34 & 34 & 30 & 33 \\
\hline $\begin{array}{l}\text { Pergelangan/ } \\
\text { tangan }\end{array}$ & 36 & 26 & 26 & 26 & 26 & 26 & 27.7 \\
\hline Leher & 16 & 16 & 18 & 18 & 16 & 18 & 17 \\
\hline Mengemudi & 1 & 1 & 1 & 1 & 1 & 1 & 1 \\
\hline Getaran & 4 & 9 & 9 & 9 & 9 & 9 & 8.2 \\
\hline $\begin{array}{l}\text { Kecepatan } \\
\text { kerja }\end{array}$ & 4 & 9 & 9 & 4 & 4 & 1 & 5.2 \\
\hline stress & 16 & 16 & 4 & 16 & 9 & 9 & 11.7 \\
\hline
\end{tabular}


Tabel di atas menunjukkan bahwa tingkat resiko akibat kerja berada pada area bahu/ lengan, pergelangan tangan dan punggung. Hal ini juga diperkuat dengan hasil kuisioner yang dibagikan kepada pekerja tersebut.

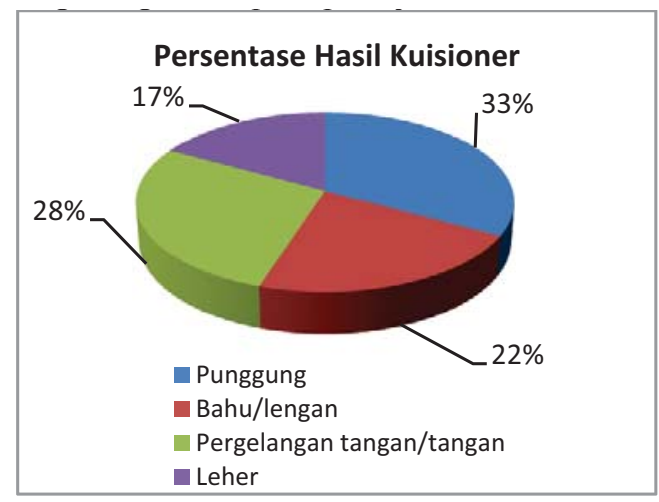

Gambar 5 Persentase Hasil Kuesioner

Selanjutnya dari tabel 5 dihitung nilai exposure level untuk menentukan tindakan apa yang dilakukan berdasarkan dari hasil perhitungan total exposure score. Maka untuk aktivitas proses perendaman bahan baku yaitu pengangkatan air manual oleh pekerja memiliki action level $\geq 70 \%$ yaitu dilakukan penelitian dan perubahan secepatnya.

Tabel 6 Persentase Exposure level

\begin{tabular}{|c|l|l|}
\hline Pekerja & $\begin{array}{c}\text { Perhitungan Exposure } \\
\text { Exposure }\end{array}$ \\
\hline 1 & $\mathrm{E} \%=149 / 178 \times 100 \%=0.84$ & $84 \%$ \\
\hline 2 & $\mathrm{E} \%=133 / 178 \times 100 \%=0.75$ & $75 \%$ \\
\hline 3 & $\mathrm{E} \%=119 / 178 \times 100 \%=0.67$ & $67 \%$ \\
\hline 4 & $\mathrm{E} \%=130 / 178 \times 100 \%=0.73$ & $73 \%$ \\
\hline 5 & $\mathrm{E} \%=121 / 178 \times 100 \%=0.68$ & $68 \%$ \\
\hline 6 & $\mathrm{E} \%=116 / 178 \times 100 \%=0.65$ & $65 \%$ \\
\hline
\end{tabular}

Berdasarkan hasil QEC diatas maka pada aktivitas Manual Material Handling di stasiun penggilingan yaitu proses perendaman bahan baku dan pembersihan bahan baku maka perlu dilakukan perbaikan meja kerja dengan merancang meja yang sesuai dengan postur tubuh pekerja. Berikut adalah data antropometri pekerja yang menjadi titik fokus dalam memberikan rancangan.
Tabel 7 Hasil Pengukuran

\begin{tabular}{|l|c|c|c|}
\hline \multirow{2}{*}{ List Pekerja } & \multicolumn{3}{|c|}{ Data Hasil Pengukuran } \\
\cline { 2 - 4 } & JT(cm) & RT(cm) & TSB $(\mathrm{cm})$ \\
\hline Pekerja1 & 70 & 176 & 130 \\
\hline Pekerja 2 & 68 & 175 & 129 \\
\hline Pekerja 3 & 70 & 170 & 125 \\
\hline Pekerja 4 & 68 & 168 & 122 \\
\hline Pekerja 5 & 72 & 176 & 130 \\
\hline Pekerja 6 & 69 & 172 & 127 \\
\hline Mean & 69.5 & 172.83 & 127.1 \\
\hline SD & 1.52 & 3.37 & 3.19 \\
\hline BKA & 72.53 & 179.58 & 133.5 \\
\hline BKB & 66.47 & 166.09 & 120.7 \\
\hline Persentil 95 th & 71.99 & 178.38 & 132.4 \\
\hline Persentil 5th & 67.01 & 167.29 & 121.9 \\
\hline
\end{tabular}

\section{Prototype Rancangan Meja Kerja}

Prototype rancangan meja kerja yang dirancang adalah meja bahan baku dengan prinsip meja wastafel, dimana dengan prinsip kerja seperti ini memudahkan operator untuk merendam dan membilas bahan baku tanpa perlu mengangkat air lagi.

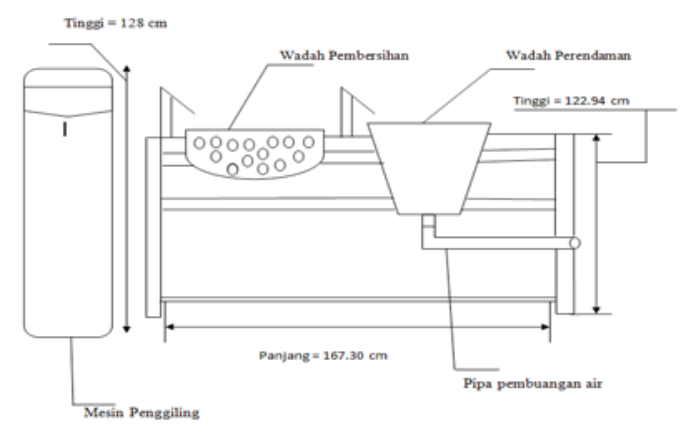

Gambar 6 Prototype meja kerja

Ukuran meja kerja yang diberikan berdasarkan data antropometri pekerja

1. Panjang jangkauan tangan $($ persentil 5) $=$ $69.5-(1.645 \times 1,52)=67,01 \mathrm{~cm}$.Dari hasil perhitungan data panjang jangkauan tangan dengan nilai persentil 5 yaitu $67,01 \mathrm{~cm}$.

2. Panjang rentang tangan $($ persentil 5) $=$ $172.83-(1,64 \times 3.37)=167.30 \mathrm{~cm}$. Dari hasil perhitungan data panjang rentang tangan dengan nilai persentil 5 yaitu $167.30 \mathrm{~cm}$.

3. Panjang Tinggi siku berdiri $($ persentil 5) $=$ $69.5-(1,64 \times 3.19)=121.94 \mathrm{~cm}$ 
Dari hasil perhitungan data panjang rentang tangan dengan nilai persentil 5 yaitu $167.30 \mathrm{~cm}$. Untuk menentukan ukurun tinggi meja diperoleh dari ukuran tinggi siku berdiri dengan persentil 5 ditambah dengan toleransi sepatu safety sehingga tinggi siku berdiri $=121.94 \mathrm{~cm}+1 \mathrm{~cm}=122.94 \mathrm{~cm}$

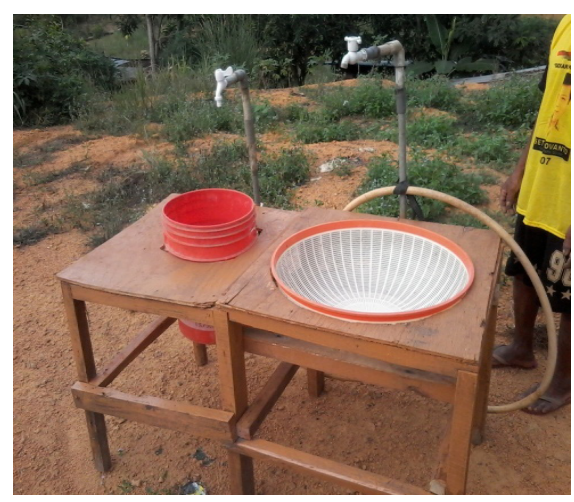

Gambar 7 Rancangan meja kerja bahan baku kacang kedelai

Pada gambar 7 adalah meja kerja yang didesain dengan prinsip wastafel ini bertujuan untuk memudahkan proses perendaman dan pembersihan bahan baku kacang kedelai, dimana proses perendaman bahan baku kacang kedelai direndam dan dibilas dengan cara memutar keran atau valve air menggunakan keran atau valve tanpa mengambil air manual dengan ember.

\section{Perbandingan QEC (Quick Exposure Check) Setelah Rancangan}

Berikut ini adalah skor QEC perbandingan sebelum dan setelah perancangan

Tabel 8 Hasil perbandingan exposure

\begin{tabular}{|c|c|c|}
\hline \multirow[b]{2}{*}{ Pekerja } & \multicolumn{2}{|c|}{ Hasil exposure } \\
\hline & $\begin{array}{c}\text { Sebelum } \\
\text { perancangan }\end{array}$ & $\begin{array}{c}\text { Sesudah } \\
\text { perancangan }\end{array}$ \\
\hline 1 & $84 \%$ & $35 \%$ \\
\hline 2 & $75 \%$ & $38 \%$ \\
\hline 3 & $67 \%$ & $34 \%$ \\
\hline 4 & $73 \%$ & $40 \%$ \\
\hline 5 & $68 \%$ & $34 \%$ \\
\hline 6 & $65 \%$ & $32 \%$ \\
\hline Rata -rata & $72 \%$ & $36 \%$ \\
\hline
\end{tabular}

Pada tabel diatas terdapat perbedaan sebelum dan sesudah perancangan meja kerja, dimana setelah perancangan meja kerja terdapat penurunan hasil persentase exposure yaitu dari $72 \%$ menurun menjadi $36 \%$.

\section{Kesimpulan}

Dari hasil penelitian ini, diperoleh hasil bahwa QEC aktual sebelum perancangan meja kerja adalah rata - rata $72 \%$, tindakan yang harus diambil berdasarkan nilai yang dihasilkan dalam perhitungan exposure levelbila total exposure level $\geq$ $70 \%$ yaitu dilakukan penelitian dan perubahan secepatnya. Dengan nilai QEC aktual 72\%, maka perlunya sebuah perancangan meja kerja untuk mengurangi persentase QEC tersebut. Rancangan meja kerja dilakukan dengan prinsip wastafel yang ergonomis dengan ukuran jangkauan tangan $=67.01$ $\mathrm{cm}$, panjang rentang tangan $=167.30 \mathrm{~cm}$, tinggi siku berdiri $=122.94 \mathrm{~cm}$ untuk dapat dipergunakan dengan aman dan nyaman. Setelah dirancang meja kerja dengan prinsip wastafel ergonomis, maka setelah perancangan meja kerja yang didapat persentase rata-rata QEC 36\% ini berarti QEC hasil rancangan dapat mengurangi keluhan dan rasa dibawah maksimum \% QEC (40\%)

\section{Saran}

1. Penelitian ini dapat dilanjutkan dengan menganalisa produktivitas pabrik tahu sumedang dan diimplementasikan guna meningkatkan sistem kerja yang baik bagi operator pabrik tahu.

2. Meja kerja yang sudah dirancang agar dapat digunakan dan dapat mengurangi keluhan operator dan dapat mengurangi pekerjaan manual material handling.

\section{Ucapan Terima Kasih}

Peneliti mengucapkan terima kasih kepada Pak Odon yang memberikan tempat UKM Tahu Sumedang sebagai tempat penelitian dan Bapak/Ibu dosen serta mahasiswa yang mendukung penelitian ini 


\section{DAFTAR PUSTAKA}

[1] Santoso.G. 2013. Ergonomi Terapan, Penerbit PT Prestasi Pustakarya, Jakarta

[2] Wignjosoebroto, S. 2006. Teknik Analisis Untuk Peningkatan Produktivitas Kerja. Guna Widya, Surabaya

[3] Ilman A, Yuniar, Helianty Y.2013. Rancangan Perbaikan Sistem Kerja dengan Metode Quick Exposure Check (QEC) di Bengkel Sepatu X di Cibaduyut. Jurusan Teknik Industri Itenas | No. 2 | Vol. 1 Hal 120-128 ;http\%3A\%2F\%2Fjurnalonline.itenas.ac.id diakses tanggal 1 Oktober 2016

[4] Tarwaka., Solichul BA., Lilik S. 2004. Ergonomi Untuk Keselamatan, Kesehatan Kerja dan Produktivitas. Surakarta: UNIBA Press.
[5] Nurmianto, E. 2013.Ergonomi Konsep Dasar dan Aplikasinya, Penerbit PT Graha Ilmu, Institut Teknologi Sepuluh November.

[6] Iriastadi, H \& Yassierli. 2014. Ergonomi Suatu Pengantar, Penerbit PT Remaja Rosdakarya, Bandung

[7] Andi, W, 2008, "Analis postur kerja dan perancangan alat bantu untuk aktivitas manual material handling industrikecil", http://eprints.ums.ac.id/1720/2/D600020091. $p d f$, (diunduh pada tanggal 19 April 2016)

[8] Anna, B \& Chandra.Modul Praktikum Statistika \& SPSS. Batam: Fakultas Teknik Industri, Universitas Riau Kepulauan

[9] Neville, Stanton, 2004, Handbook of Human Factor and Ergonomics Methods, Florida: CNC Press 